\title{
Grazing in silvopastoral systems: multiple solutions for diversified benefits
}

\author{
Elvira Sales-Baptista (D) Maria Isabel Ferraz-de-Oliveira $\mathbb{C}$
}

Received: 12 November 2020/ Accepted: 21 November 2020/Published online: 9 January 2021

(C) The Author(s), under exclusive licence to Springer Nature B.V. part of Springer Nature 2021

\begin{abstract}
Silvopastoral systems are multifunctional systems that combine herbage, shrub and tree layers with grazing animals in a single site. The multiple possible combinations of components within these systems creates different options that have in common the capacity to deliver positive outcomes related to land productivity and environmental and climatic benefits. This editorial provides a perspective of the diversity of ancient and more recent silvopastoral systems and their main benefits. The major challenges for both systems are different. Ancient silvopastoral systems, which originated on cultural grounds, deal mostly with conservation issues, while intensive silvopastoral systems, founded on technological changes of the grazing livestock production model, are more production driven but also concerned with climatic changes. Both types of system share similar benefits, and in this special issue we look at positive outcomes in the perspective of grazing animals, highlighting production and welfare. The purpose of
\end{abstract}

Elvira Sales-Baptista and Maria Isabel Ferraz-de-Oliveira: Shared first authorship.

E. Sales-Baptista · M. I. Ferraz-de-Oliveira $(\square)$

Mediterranean Institute for Agriculture, Environment and

Development (MED), Departamento de Zootecnia,

Universidade de Évora, P.O. Box 94, 7002-554 Évora,

Portugal

e-mail: mifo@uevora.pt

E. Sales-Baptista

e-mail: elsaba@uevora.pt this special issue is to contribute to gathering and sharing the knowledge emerging from grazing on different silvopastoral systems, promoting a common ground for future integrative research approaches.

Keywords Animal welfare - Ecosystem services · Resilience - Intensive silvopastoral systems - Ancient silvopastoral systems

\section{Introduction}

Different regions across the world share land use systems that have in common the presence of trees, shrubs, herbage, and grazing livestock within the same paddock under various management practices (Cubbage et al. 2012; Jose and Dollinger 2019; Jose et al. 2019). Silvopastoral systems are diverse and complex production systems and have been claimed to be environmentally resilient (Hanisch et al. 2019) while delivering ecosystem services that are vital to community wellbeing (Plieninger and Huntsinger 2018). Besides the provisioning services they deliver (e.g. timber, animal products), silvopastoral systems also produce other ecosystem services including regulatory (e.g., climate regulation, air regulation), supporting (e.g., nutrient cycling, water cycling, soil formation) and cultural (e.g., aesthetic values, educational values) 
(Wallace 2007; Jose 2009; Surová et al. 2018; Hanisch et al. 2019).

The flexibility of silvopastoral systems arises from the many possible combinations of their components, which provides a wide range of options to meet different management goals. The high diversity of solutions of livestock grazing management across the world also adds complexity. However, the complexity can be broken down into evaluable parts without losing sight of the whole picture. A common and fundamental concept of any silvopastoral system is resource sharing in time and space. Furthermore, the common underlying principles highlight the importance of being biologically possible, ecologically sustainable, socially acceptable, and economically feasible (Sharrow et al. 2009; Jose et al. 2019). Within this framework we can learn from each other, extracting lessons and answers to common problems. This approach can promote silvopastoral systems as a solution, which is particularly important within scenarios of food scarcity, global warming and population growth.

Additionally, these multifunctional systems provide alternative solutions that respond to the increasing public awareness of the ethics of food production and animal welfare, linked to industrialized livestock operations (Vanhonacker et al. 2009; Lang 2010; Ellison et al. 2017). Silvopastoral systems embrace low input animal production while providing the environmental accountability claimed by consumers (Jose and Dollinger 2019).

The purpose of this special issue is to contribute to gather and share the knowledge emerging from grazing on different silvopastoral systems, addressing the management effects on productivity and on animal welfare.

\section{Different silvopastoral systems as diversified solutions for sustainability}

Silvopastoral systems with different compositions and structures have been around for centuries across the world (Velásquez 2018; Jose and Dollinger 2019). These ancient native systems occurred wherever there were trees, from temperate to tropical areas. They have in common their long history (300-700 years), the presence of native trees and traditional practices that include grazing of livestock, pruning or pollarding for fodder, firewood collection and charcoal production, non-wood forest product collection, and farming. These ancient silvopastoral systems mostly cover large areas and have marked characteristics and specific names. Examples of such systems include the Montado and the Dehesa in the south-easternmost part of Europe (3.5 million ha) (Pinto-Correia et al. 2011), the Spinal in Chile (3.8 million ha) (Ovalle et al. 1990), and the Galajars in Iran (5.2 million ha) (Valipour et al. 2014). Other more fragmented smallholder native systems also occur. Although with no specific designation, these systems are deeply rooted in the local cultural heritage (e.g. Indonesia) (Roshetko et al. 2007).

In contrast with ancient silvopastoral systems, an improved and more technologically demanding type of silvopastoral system has emerged recently. In the last two decades, a change of paradigm in Latin American cattle ranching brought about silvopastoral systems as an economical, ecological and socially productive alternative to either forestry or animal husbandry on their own (Murgueitio et al. 2011; Peri et al. 2016). The development of this top-down approach to silvopastoral systems was supported by research and large political and financial projects (Murgueitio et al. 2013) that included payments for environmental services, technical and specialized assistance, and high financial incentives from governmental agencies. The search for adapted solutions may introduce tree species in natural grasslands or livestock into native mixed forests. More often they use high-density plantation of both trees and fodder shrubs, in different architectural arrangements, combined with improved grasses and intensive rotational grazing practices. This innovative silvopastoral system, pioneered in Colombia, expanded to several Latin American countries (Chará et al. 2019). Such systems have been named as Intensive Silvopastoral Systems. As Murgueitio et al. (2011) stated, their name may be misleading because what is intensive "is not the use of capital, labor, or chemical inputs, but rather the efficiency of biological processes such as photosynthesis, nitrogen fixation, solubilization of soil phosphorus, and the enhancement of soil biological activity" (p. 1656).

This special issue offers examples of both ancient and more recent silvopastoral systems. Maintaining the ecological status is one of the main concerns with ancient silvopastoral systems (Valipour et al. 2014; 
Sales-Baptista et al. 2016). Several of these systems are essential for providing habitats for wildlife, being considered as "hot spots" for biodiversity, and recognized as high nature value farm systems (Ferraz-de-Oliveira et al. 2016). The Iberian silvopastoral systems are further responsible for $61 \%$ of the world's cork production (Sierra-Pérez et al. 2015). However, these ancient silvopastoral systems are frequently under threat, due to either rural depopulation and consequent abandonment or, at the other extreme of the management spectrum, chronic overuse, including overgrazing (Sales-Baptista et al. 2016). The abandonment of rural areas and the lack of grazing activity (undergrazing) leads to shrub encroachment, greater fuel load and consequently increases risk of fire (Jose et al. 2019). The paper by Ramos-Font et al. (2020), in this special issue, evaluates the potential for pasture improvement and restoration at silvopastoral sites in mountain areas after fires. The authors explore the best restoration plans, aiming to understand which plant species and fertilization techniques perform best in terms of forage and seed yield. Sheep penning alone or together with mycorrhizal treatment resulted in greater forage yields, evidencing the importance of grazing animals for restauration processes in silvopastoral systems. Another threat to the resilience of these ancient systems comes from the low and variable forage mass production due to frequent droughts and often limited soil fertility. Forage mass limits management decisions on stocking density thus affecting overall productivity of the system. The paper from Serrano et al. (2020), in this special issue, suggests the use of proximal sensors as a straightforward and economical tool for pasture quantity and quality assessment. Monitoring the system supports more informed farmer decisions, enabling more adaptive management and efficient use of resources.

In contrast with ancient silvopastoral systems, the main drive of intensive silvopastoral systems is livestock production within a frame of ecological concerns. As stated before these systems are tailored to local conditions and may be diverse. The paper by Cardozo-Herrán et al. (2020), in this special issue, evaluated the productivity of lactating goats in México, under a native vegetation grazing system, a grass monoculture system and an intensive silvopastoral system based on tanzania grass (Megatyrsus maximus) and leucaena srubs. Another paper by Pent et al. (2020b), reported results obtained in the United
States of America, in hardwood silvopastures, using Juglans nigra and Gleditsia triacanthos trees on a tall fescue (Schedonorus arundinaceous) pasture. Both ancient and intensive silvopastoral systems, spread across continents, using different management grazing practices and animal species, illustrate a wide array of possible combinations available for an integrated, sustainable land use approach.

\section{Positive outcomes of silvopastoral systems}

Silvopastoral systems produce a number of positive outcomes when compared with open pastures, including production benefits [e.g. land productivity (Pent 2020a); animal welfare (Broom et al. 2013)], environmental benefits [e.g., increased biodiversity (Mosquera-Losada et al. 2009)] and climatic benefits (e.g. carbon sequestration (Lorenz and Lal 2014); methane emissions reduction (Thornton and Herrero 2010)]. Grazing animal are net contributors to the ecosystems services produced in silvopasture systems. Examples include, farm animal genetic resources preservation, soil fertility/nutrient recycling, shrubs encroachment control/fire control, seed dispersal/habitat provision, knowledge systems and educational values (Leroy et al. 2018). In this special issue we highlight the positive outcomes arriving from increased production and animal welfare.

The meta-analysis conducted by Pent (2020a) on productivity in temperate regions compared the production of single silvopasture components (tree, forage, and livestock) with the production of the same components either within the open pasture or forest managed separately. The analysis evidenced that silvopastoral practices improve the overall productivity of land up to 55\%, despite a reduction in individual forage, livestock, or tree productivity. In tropical systems, a review by Cuartas Cardona et al. (2014) reported a four-fold increase in meat production per hectare in intensive silvopastoral systems when compared to conventional extensive grazing systems. In this special issue, goat's milk yield was evaluated when animals grazed a grass monoculture, a native silvopastoral, or an intensive silvopastoral system (Cardozo-Herrán et al. 2020). However, in this study, there were no differences in daily milk production $\left(\mathrm{g}\right.$ animal $^{-1}$ day ${ }^{-1}$ ) between systems. One of the reasons for the reported increased animal productivity 
in intensive silvopastoral systems is their larger protein input through fodder, shrubs and legumes. Three species have so far shown the best results: the Mexican sunflower Tithonia diversifolia, bay cedar Guazuma ulmifolia, and in particular leucaena Leucaena leucocephala. Considerable research on leucaena has been carried out during the last 50 years. Nevertheless, information on a more efficient digestive use is essential, namely by improving dietary mixtures. That was the purpose of the work by FloresCocas et al. (2020), presented in this special issue, who used two energy sources (sugar cane molasses and rice polishing) to supplement a diet based on leucaena to assess the effect on composition and milk yield of dual purpose cows.

Besides milk, meat is also a product from silvopastoral systems, though the most profitable animal product in silvopastoral systems that cover large areas. Livestock meat production is carried out worldwide, mostly under extensive production systems. Although these systems are more nature-mimicking, they are not necessarily more sustainable. While an animal's natural behavior may be freely expressed in extensive systems, they are still vulnerable to other welfare challenges (Dwyer 2009). Thus, assessment of welfare in extensive systems is greatly needed, though hampered by the irregularity and unpredictability of the environment (Waterhouse 1996).

Silvopastoral grazing systems, although extensive, have specific features that offer welfare advantages related to comfort and feeding domains. Among the several welfare benefits reviewed by Broom (2017), the improvement in levels of nutrition (Murgueitio et al. 2011), health (Tarazona Morales et al. 2017), comfort (Mancera and Galindo 2011), and reduction of fear (Ocampo et al. 2011) are highlighted. In this special issue, the work by Pent et al. (2020b) underlined the importance of trees to moderate the impact of environmental conditions on sheep body temperatures. Using intravaginal temperature sensors, they found significant differences between animals grazing in open pastures and those benefiting from tree shade. Sheep in open pastures experienced higher fluctuations in core temperature between day and night as well as over the months. Similar results, on the effects of shade on the welfare of animals were reported by Deniz et al. (2019).

\section{Conclusion}

Despite differences in geographical locations and types of trees, shrubs and animals, the dynamics of interactions among silvopastoral components are equally important for the characterization of the systems. General principles of functioning, based on those relations, may be inferred and further shared among different systems; for example, the experience gained in tropical silvopastoral systems may prove useful for temperate areas and vice versa. A further integrative research approach to understand vulnerabilities and enhance the resilience of extensive grazing livestock farming is a common goal to preserve and improve silvopastoral systems worldwide.

Authors' contributions ESB and MIFO contributed equally to the preparation of this manuscript and share co-first authorship.

Funding The study was funded by National Funds through FCT (Foundation for Science and Technology) under the Project UIDB/05183/2020.

\section{References}

Broom DM (2017) Components of sustainable animal production and the use of silvopastoral systems. Revista Brasileira de Zootecnia 46(8):683-688. https://doi.org/10.1590/ S1806-92902017000800009

Broom DM, Galindo FA, Murgueitio E (2013) Sustainable, efficient livestock production with high biodiversity and good welfare for animals. Proc R Soc B Biol Sci 280(1771):20132025. https://doi.org/10.1098/rspb.2013. 2025

Cardozo-Herrán M, Ayala-Burgos A, Aguilar-Pérez C, Ramírez-Avilés L, Ku-Vera J, Solorio-Sánchez FJ (2020) Productivity of lactating goats under three grazing systems in the tropics of Mexico. Agrofor Syst. https://doi.org/10. 1007/s10457-019-00384-6

Chará J, Reyes E, Peri P, Otte J, Arce E, Schneider F (2019) Silvopastoral systems and their contribution to improved resource use and sustainable development goals: evidence from Latin America. FAO, CIPAV and Agri Benchmark, Cali, p 60

Cuartas Cardona CA, Naranjo Ramírez JF, Tarazona Morales AM, Murgueitio Restrepo E, Chará Orozco JD, Ku Vera J et al (2014) Contribution of intensive silvopastoral systems to animal performance and to adaptation and mitigation of climate change. Revista Colombiana de Ciencias Pecuarias 27(2):76-94

Cubbage F, Balmelli G, Bussoni A, Noellemeyer E, Pachas AN, Fassola $\mathrm{H}$ et al (2012) Comparing silvopastoral systems and prospects in eight regions of the world. Agrofor Syst 
86(3):303-314. https://doi.org/10.1007/s10457-012-9482$\mathrm{Z}$

Deniz M, Schmitt Filho AL, Farley J, de Quadros SF, Hötzel MJ (2019) High biodiversity silvopastoral system as an alternative to improve the thermal environment in the dairy farms. Int J Biometeorol 63(1):83-92. https://doi.org/10. 1007/s00484-018-1638-8

Dwyer CM (2009) Welfare of sheep: providing for welfare in an extensive environment. Small Ruminant Res 86(1-3):14-21. https://doi.org/10.1016/j.smallrumres. 2009.09.010

Ellison B, Brooks K, Mieno T (2017) Which livestock production claims matter most to consumers? Agric Hum Values 34(4):819-831. https://doi.org/10.1007/s10460017-9777-9

Ferraz-de-Oliveira MI, Azeda C, Pinto-Correia T (2016) Management of Montados and Dehesas for high nature value: an interdisciplinary pathway. Agrofor Syst 90(1):1-6. https://doi.org/10.1007/s10457-016-9900-8

Flores-Cocas JM, Aguilar-Pérez CF, Ramírez-Avilés L, Solorio-Sánchez FJ, Ayala-Burgos AJ, Ku-Vera JC (2020) Use of rice polishing and sugar cane molasses as supplements in dual-purpose cows fed Leucaena leucocephala and Pennisetum purpureum. Agrofor Syst. https://doi.org/ 10.1007/s10457-019-00434-z

Hanisch AL, Negrelle RR, Bonatto RA, Nimmo ER, Lacerda AEB (2019) Evaluating sustainability in traditional silvopastoral systems (caívas): looking beyond the impact of animals on biodiversity. Sustainability 11(11):3098. https://doi.org/10.3390/su11113098

Jose S (2009) Agroforestry for ecosystem services and environmental benefits: an overview. Agrofor Syst 76(1):1-10. https://doi.org/10.1007/s10457-009-9229-7

Jose S, Dollinger J (2019) Silvopasture: a sustainable livestock production system. Agrofor Syst 93(1):1-9. https://doi.org/ 10.1007/s10457-019-00366-8

Jose S, Kumar BM, Walter D (2019) Ecological considerations in sustainable silvopasture design and management. Agrofor Syst 93:317-331. https://doi.org/10.1007/s10457016-0065-2

Lang T (2010) From ‘value-for-money'to ‘values-for-money'? Ethical food and policy in Europe. Environ Plan A 42(8):1814-1832. https://doi.org/10.1068/a4258

Leroy G, Hoffmann I, From T, Hiemstra SJ, Gandini G (2018) Perception of livestock ecosystem services in grazing areas. Anim Int J Anim Biosci 12(12):2627-2638. https:// doi.org/10.1017/s1751731118001027

Lorenz K, Lal R (2014) Soil organic carbon sequestration in agroforestry systems. A review. Agron Sustain Dev 34(2):443-454. https://doi.org/10.1007/s13593-014-0212$\mathrm{y}$

Mancera AK, Galindo F (2011) Evaluation of some sustainability indicators in extensive bovine stockbreeding systems in the state of Veracruz. In: VI Reunión Nacional de Innovación Forestal, León Guanajauato, México, p 31

Mosquera-Losada MR, Rodríguez-Barreira S, López-Díaz ML, Fernández-Núñez E, Rigueiro-Rodríguez A (2009) Biodiversity and silvopastoral system use change in very acid soils. Agr Ecosyst Environ 131(3-4):315-324. https://doi. org/10.1016/j.agee.2009.02.005
Murgueitio E, Calle Z, Uribe F, Calle A, Solorio B (2011) Native trees and shrubs for the productive rehabilitation of tropical cattle ranching lands. Forest Ecol Manag 261(10):1654-1663. https://doi.org/10.1016/j.foreco. 2010.09.027

Murgueitio E, Chará JD, Solarte AJ, Uribe F, Zapata C, Rivera JE (2013) Agroforestería Pecuaria y Sistemas Silvopastoriles Intensivos (SSPi) para la adaptación ganadera al cambio climático con sostenibilidad. Rev Colomb Cienc Pecu 26:313-316

Ocampo A, Cardozo A, Tarazona A, Ceballos M, Murgueitio E (2011) La investigación participativa en bienestar y comportamiento animal en el trópico de América: oportunidades para nuevo conocimiento aplicado. Rev Colomb Cienc Pecu 24:332-346

Ovalle C, Aronson J, Del Pozo A, Avendano J (1990) The espinal: agroforestry systems of the Mediterranean-type climate region of Chile. Agrofor Syst 10(3):213-239. https://doi.org/10.1007/BF00122913

Pent GJ (2020a) Over-yielding in temperate silvopastures: a meta-analysis. Agrofor Syst 94:1741-1758. https://doi.org/ 10.1007/s10457-020-00494-6

Pent GJ, Fike JH, Kim I (2020b) Ewe lamb vaginal temperatures in hardwood silvopastures. Agrofor Syst. https://doi.org/ 10.1007/s10457-018-0221-y

Peri PL, Dube F, Varella A (2016) Silvopastoral systems in the subtropical and temperate zones of South America: an overview. In: Peri PL, Dube F, Varella A (eds) Silvopastoral systems in Southern South America. Advances in Agroforestry, vol 11. Springer, Cham, pp 1-8. https://doi. org/10.1007/978-3-319-24109-8_1

Pinto-Correia T, Ribeiro N, Sá-Sousa P (2011) Introducing the montado, the cork and holm oak agroforestry system of Southern Portugal. Agrofor Syst 82(2):99. https://doi.org/ 10.1007/s10457-011-9388-1

Plieninger T, Huntsinger L (2018) Complex rangeland systems: integrated social-ecological approaches to silvopastoralism. Rangeland Ecol Manag 71(5):519-525. https://doi. org/10.1016/j.rama.2018.05.002

Ramos-Font ME, Tognetti-Barbieri MJ, González-Rebollar JL, Robles-Cruz AB (2020) Potential of wild annual legumes for mountain pasture restoration at two silvopastoral sites in southern Spain: promising species and soil-improvement techniques. Agrofor Syst. https://doi.org/10.1007/s10457018-0340-5

Roshetko JM, Lasco RD, Angeles MSD (2007) Smallholder agroforestry systems for carbon storage. Mitig Adapt Strat Glob Change 12:219-242. https://doi.org/10.1007/s11027005-9010-9

Sales-Baptista E, d'Abreu MC, Ferraz-de-Oliveira MI (2016) Overgrazing in the Montado? The need for monitoring grazing pressure at paddock scale. Agrofor Syst 90(1):57-68. https://doi.org/10.1007/s10457-014-9785-3

Serrano J, Sales-Baptista E, Shahidian S, da Silva JM, de Oliveira IF, de Castro JL et al (2020) Proximal sensors for monitoring seasonal changes of feeding sites selected by grazing ewes. Agrofor Syst. https://doi.org/10.1007/ s10457-018-0219-5

Sharrow SH, Brauer D, Clason TR (2009) Silvopastoral practices. In: HE "Gene" Garrett (ed) North American Agroforestry: An Integrated Science and Practice, 2nd 
edition. pp 105-131. https://doi.org/10.2134/2009. northamericanagroforestry.2ed.c6

Sierra-Pérez J, Boschmonart-Rives J, Gabarrell X (2015) Production and trade analysis in the Iberian cork sector: economic characterization of a forest industry. Resour Conserv Recycl 98:55-66. https://doi.org/10.1016/j. resconrec.2015.02.011

Surová D, Ravera F, Guiomar N, Sastre RM, Pinto-Correia T (2018) Contributions of iberian silvo-pastoral landscapes to the well-being of contemporary society. Rangeland Ecol Manag 71(5):560-570. https://doi.org/10.1016/j.rama. 2017.12.005

Tarazona Morales AM, Ceballos MC, Correa Londoño G, Cuartas Cardona CA, Naranjo Ramírez JF, Paranhos da Costa MJR (2017) Welfare of cattle kept in intensive silvopastoral systems: a case report. Revista Brasileira de Zootecnia 46(6):478-488. https://doi.org/10.1590/s180692902017000600002

Thornton PK, Herrero M (2010) Potential for reduced methane and carbon dioxide emissions from livestock and pasture management in the tropics. Proc Natl Acad Sci 107(47):19667-19672. https://doi.org/10.1073/pnas. 0912890107

Valipour A, Plieninger T, Shakeri Z, Ghazanfari H, Namiranian M, Lexer MJ (2014) Traditional silvopastoral management and its effects on forest stand structure in northern Zagros, Iran. Forest Ecol Manag 327:221-230. https://doi.org/10. 1016/j.foreco.2014.05.004

Vanhonacker F, Verbeke W, Van Poucke E, Buijs S, Tuyttens FA (2009) Societal concern related to stocking density, pen size and group size in farm animal production. Livestock Sci 123(1):16-22. https://doi.org/10.1016/j.livsci.2008.09. 023

Velásquez AYC (2018) Land use changes and vegetation dynamics in a silvopastoral system: effect on their ecological structure and carbon storage. Doctoral dissertation, Universidad Politécnica de Madrid

Wallace KJ (2007) Classification of ecosystem services: problems and solutions. Biol Conserv 139(3-4):235-246. https://doi.org/10.1016/j.biocon.2007.07.015

Waterhouse A (1996) Animal welfare and sustainability of production under extensive conditions-a European perspective. Appl Anim Behav Sci 49(1):29-40. https://doi. org/10.1016/0168-1591(95)00666-4

Publisher's Note Springer Nature remains neutral with regard to jurisdictional claims in published maps and institutional affiliations. 